\title{
Journal of Gerontology: Biological Sciences
}

\section{Testicular aging: an overview of ultrastructural, cellular and molecular alterations}

\begin{tabular}{|c|c|}
\hline Journal: & Journal of Gerontology: Biological Sciences \\
\hline Manuscript ID & Draft \\
\hline Manuscript Type: & Review in Depth \\
\hline Date Submitted by the Author: & $\mathrm{n} / \mathrm{a}$ \\
\hline Complete List of Authors: & $\begin{array}{l}\text { Santiago, Joana; University of Aveiro, Department of Medical Sciences, } \\
\text { Institute for Biomedicine - iBiMED } \\
\text { Silva, Joana; University of Aveiro, Department of Medical Sciences, } \\
\text { Institute for Biomedicine - iBiMED; Institute of Biomedical Sciences Abel } \\
\text { Salazar (ICBAS), Unit for Multidisciplinary Investigation in Biomedicine, } \\
\text { University of Porto; Institute for Innovation and Health Research (I3S), } \\
\text { University of Porto } \\
\text { Alves, Marco; Institute of Biomedical Sciences Abel Salazar (ICBAS), } \\
\text { Department of Microscopy, Laboratory of Cell Biology, and Unit for } \\
\text { Multidisciplinary Research in Biomedicine (UMIB) } \\
\text { Oliveira, Pedro; Institute for Innovation and Health Research (I3S), } \\
\text { University of Porto; Institute of Biomedical Sciences Abel Salazar (ICBAS), } \\
\text { Department of Microscopy, Laboratory of Cell Biology, and Unit for } \\
\text { Multidisciplinary Research in Biomedicine (UMIB); Faculty of Medicine, } \\
\text { University of Porto, Department of Genetics } \\
\text { Fardilha, Margarida; University of Aveiro, Department of Medical Sciences, } \\
\text { Institute for Biomedicine - iBiMED }\end{array}$ \\
\hline Keywords: & Age-Related Pathology, Animal Model, Biology of Aging, Human Aging \\
\hline Alternate Keyword: & Testicular Aging \\
\hline
\end{tabular}




\section{Testicular aging: an overview of ultrastructural, cellular and molecular alterations}

Joana Santiago ${ }^{\mathrm{a}}$, Joana V. Silva ${ }^{\mathrm{a}, \mathrm{b}, \mathrm{c}}$, Marco G. Alves ${ }^{\mathrm{d}}$, Pedro F. Oliveira ${ }^{\mathrm{c}, \mathrm{d}, \mathrm{e}}$, Margarida Fardilha $^{\mathrm{a}}$

a Laboratory of Signal Transduction, Department of Medical Sciences, Institute of Biomedicine - iBiMED, University of Aveiro, 3810-193 Aveiro, Portugal

${ }^{\mathrm{b}}$ Institute of Biomedical Sciences Abel Salazar (ICBAS), Unit for Multidisciplinary Investigation in Biomedicine, University of Porto, 4050-313 Porto, Portugal.

${ }^{c}$ Institute for Innovation and Health Research (I3S), University of Porto, 4200-135 Porto, Portugal.

${ }^{\mathrm{d}}$ Department of Microscopy, Laboratory of Cell Biology, and Unit for Multidisciplinary Research in Biomedicine (UMIB), Institute of Biomedical Sciences Abel Salazar (ICBAS), University of Porto, Porto, Portugal

${ }^{\mathrm{e}}$ Department of Genetics, Faculty of Medicine, University of Porto, Porto, Portugal

\section{Corresponding author:}

Margarida Fardilha, $\mathrm{PhD}$

Department of Medical Sciences, Institute of Biomedicine - iBiMED, University of Aveiro, 3810-193 Aveiro, Portugal

Tel.: +351234247240

e-mail: $\underline{\text { mfardilha@ua.pt }}$

\section{Authors contact:}

Joana Santiago - joanasantiago@ua.pt

Joana Vieira Silva - joanavieirasilva@ua.pt

Marco G. Alves - $\underline{\text { alvesmarc@gmail.com }}$

Pedro F. Oliveira - pfobox@gmail.com 


\begin{abstract}
The trend in parenthood at an older age is rising, increasing the concerns about the reproductive ability and the consequences for the offspring's health. While in women reproductive activity stops with menopause, in men a complete cessation of the reproductive potential doesn't occur. Although alterations in semen parameters and spermatozoa DNA integrity along the aging process are well studied, the literature on testicular function deficit has been, so far, limited and controversial. This work discusses the current knowledge on testicular aging in human and other mammals, with coverage from tissue ultrastructure, to cellular and molecular alterations. Although some studies evaluate the histomorphological alterations during aging, the information is contradictory. Not only testicular morphology and histology change with age but also the testes function, resulting in variations in the levels of many hormones. Aging also affects molecules involved in mitochondria function, receptors and signaling proteins. Thus, the reproductive function of men is affected at multiple levels, not only sperm production and quality, but also the entire male reproductive tract function. However, the real impact of those age-related alterations to men fertility and reproductive health are still far from being fully understood, highlighting that research in the field is crucial.
\end{abstract}

Keywords: testis, reproductive decline, male (in)fertility 


\section{Introduction}

In modern societies, the tendency to delay parenthood due to personal choices and socioeconomic factors is increasing (1). This trend raises many concerns about the risks and consequences underneath the natural process of aging and how it affects fertility.

The reproductive decline occurs in a specie- and gender-specific manner. In women, reproductive activity ends with menopause initiation, and the negative impact of the advanced maternal age is well documented. In men, this process is gradual and a complete cessation of reproductive capacity doesn't occur (2). The reproductive decline in men results from a combination of morphological and molecular alterations in the reproductive organs. Most studies are focused either on basic seminal parameters such as concentration, motility and morphology, or on reproductive outcomes. Increased paternal age negatively affects sperm parameters, sperm DNA integrity, telomere length, chromosomal structures and epigenetic factors (1). Additionally, advanced paternal age has been associated with lower pregnancy rates, higher risk of pregnancy loss and with childhood health, particularly with higher incidence of congenital birth defects and disorders like achondroplasia, autism, schizophrenia, trisomy and some types of cancers (1). Recently, our group used an omics approach to identify differentially expressed proteins and genes from spermatozoa and seminal plasma samples across several conditions affecting the infertile aging male (3).

Although the alterations that occur in semen parameters and the impact of advanced paternal age in the offspring's health are well studied and summarized in recent reviews $(4,5)$, the impact of age on the male gonads (testes) are still poorly understood and the information is often controversial. This paper reviews the current knowledge on testis aging in human and other mammalian species. The changes in testicular size and weight, the morphological and molecular alterations associated with aging and the 
impact of age in the endocrine function of the testis are discussed. Explore the agingassociated alterations that occur in testes can possibly explain the further alterations observed in spermatozoa and this information can be used to develop strategies and new therapeutics to overcome the reproductive decline observed.

\section{A brief overview of the testicular structure}

Testes are oval structures housed in separate compartments within the scrotum. The testicular parenchyma is composed of highly convoluted seminiferous tubules where the production of spermatozoa occurs, and by interstitial tissue that surrounds the tubules, containing the Leydig cells that secrete testosterone. The seminiferous epithelium is composed of sustentacular Sertoli cells and a stratified layer of developing male germ cells (spermatogonia, spermatocytes and spermatids) (Figure 1).

\section{Impact of age on testicular volume/weight}

Testicular morphology and function are features that change between individuals and species and are affected by multiple factors including age, malnutrition and illness (6). Most of the studies performed in humans showed a decrease in testicular volume in older man (6-10). For instance, Johnson et al. (11) described that testicular volume increased during puberty, peaked at age 30 and decreased significantly after 60 years old. Testicular volume in aged men is positively associated with serum levels of some testicular hormones, such as inhibin B, bioavailable testosterone and testosterone/luteinizing hormone $(\mathrm{LH})$ ratio (9). Since inhibin B is secreted by Sertoli cells and testosterone by Leydig cells, the reduction in the levels of these hormones can result from the reduction of Sertoli and Leydig cells number which can, in part, explain the decrease in testicular volume. Contrastingly, Johnson et al. (12) reported that the 
weight of the entire testicle was similar among young men and old men, but the weight of the tunica albuginea increased by $29 \%$ in older men, indicating a decrease in testicular parenchyma. Future studies should take in consideration that the ageassociated decrease on testicular volume may result from a combination of factors, including reduction in the number and/or volume of testicular cells, due to hormonal and connective tissue alterations.

Similar alterations were reported in mice, with the testes of older animals being consistently smaller than those of younger animals $(13,14)$. However, in studies conducted with other species, like hamsters $(15,16)$, neither weight or volume of the testes changed progressively with age. These studies highlight that there is a speciesdependent effect of aging in testes characteristics and, more than descriptive measurements, there is an urgent need for mechanistic studies that may explain the specific effects of aging in each species and even in each individual.

\section{Aging and testicular morphology}

Histomorphometric and ultrastructural studies on human testes detected clear agerelated changes, which were variable among individuals $(17,18)$. These alterations included narrowing of tubular diameter, thickening of basal membrane and fibrosis, tubular sclerosis, reduction in the number of Sertoli and spermatogenic cells, vacuolization and multinucleation of cells. The major cellular and ultrastructural alterations in testes are summarized in Figure 1.

\subsection{Changes in testicular cell population}

4.1.1. Leydig cell 
Age-related modifications on Leydig cell's population are still controversial. Although some studies show that the number of Leydig cells is diminished in aged individuals $(19,20)$, investigations with the opposite results also exist $(21,22)$. A comparison between men aged 20-48 and 50-76 years old showed that the average total number of Leydig cells was reduced by $44 \%$ in the oldest group (20). However, Ichihara et al. (22) observed that the number of Leydig cells in paired testes doubled with age, although the average volume of those cells decreased. In rat, a reduction of the total cell volume of Leydig cells accompanied by the deficient ability to produce testosterone in response to LH was reported but no changes in the total number of these cells during aging were observed $(23,24)$.

The ultrastructure of Leydig cells also seems to change with age. In human, while some cells maintain their normal appearance, others acquire intranuclear Reinke crystals or paracrystalin inclusions, multiples vacuoles, lipofuscin granules and lipid droplets in the cytoplasm $(18,25)$. These cells also show signs of dedifferentiation and involution with poorly developed endoplasmic reticulum and mitochondria, as well as, presence of multinucleation (with 2 or 3 nuclei) $(18,25)$. Sasano and Ichijo (26) evaluated the vascular patterns on testis of men aged between 20 and 89 years old and showed a reduction in testicular perfusion and arteriosclerotic lesions of testicular arterioles with increasing age. The interference with blood supply may, at least partially, explain the reduction in Leydig cell number and function. In fact, the decrease in blood supply and thus, in oxygen supply and LH levels that are responsible for the stimulation of Leydig cells may also be responsible for the decrease in testosterone production in aged males. The accumulation of lipofuscin pigment was also identified in Leydig cells in old mice (27), cat (28) and horse (29) and in aged rats the volume of smooth surfaced endoplasmic reticulum per Leydig cell increased compared with young adult rats (22). 


\subsubsection{Sertoli cells}

Sertoli cells are known as the testicular "nurse cells", since the interactions between these supporting somatic cells and the germ cells are crucial for normal spermatogenesis (30). They physically support the developing germ cells during their maturation, providing nutrients and protection from immune attack (31).

It has been suggested that Sertoli cells are amongst the most vulnerable cells to aging related dysfunctions, within the male reproductive system (32). In fact, multiple alterations associated with aging have been observed in the Sertoli cell population of different mammalian species. For instance, in aged testes, a decrease in the number of Sertoli cells has been consistently reported. In men aged more than 50 years old, the number of Sertoli cells per gram of parenchyma and per testes is reduced when compared with men younger than 30 years old $(11,33,34)$, which was linked with a diminution in seminiferous epithelial volume (18). Still, a recent study showed that the germ cell/Sertoli cell ratios were maintained, with the exception of the spermatids and elongated spermatids to Sertoli cell ratios that were lower in the elderly men (35).

Moreover, multiple ultrastructural and histological alterations have been described in Sertoli cells of aged individuals. In senile rats, it was reported that Sertoli cells lacked the thin extensions of cytoplasm (pseudopodia) that engulf germ cells and residual bodies, which might account for the failure on spermatogenesis (particularly at the stage of spermatids) and on the phagocytosis of residual bodies (36). Sertoli cells of aged rats also showed a loss of the organelles cyclical variations. The cell's nucleus are prone to become more irregularly shaped and lose their typical localization, being present at various levels of the seminiferous epithelium (37). Enlarged vesicles are found at the 
base of older Sertoli cells and cytoplasmic vesicles that are common around the area of the nucleus of rat Sertoli cells tend to be longer in the older animals (36). This vesicle enlargement seems to be directly related with the age-associated reduction of the total area of endoplasmic reticulum of Sertoli cells. Moreover, in aged rats, the endoplasmic reticulum was found to be a loose, vesiculated network and not the typical elaborate, tubular and anastomotic network seen in Sertoli cells of young animals (37). A similar trend was reported in Sertoli cells of older men, which exhibited odd-shaped nuclei, vesiculated endoplasmic reticulum and irregular lysosomes (35). Some of these Sertoli cell lysosomes are large, oddly shaped, containing lipidic inclusions and are scattered all over the cytoplasm, in contrast to the distinct membrane-bound lysosomes and dense core bodies described in young individuals. They encompass large, empty intercellular spaces, which possibly were previously occupied by developing germ cells and/or could result from the loss of ability of these aged cells to break down waste products (37).

The presence of these vacuoles seems to reflect the diminished biological functions of Sertoli cells with aging (18). In fact, the increased phagocytosis of degenerating germ cells gives rise to lipid droplets in Sertoli cells cytoplasm, which can result in the excessive accumulation of both electron-lucent membrane bound lipids and electrondense lipid inclusions in older individuals, so that the Sertoli cells become incapable of eliminating these lipid bodies (38). Other Sertoli cell abnormalities such as depolarization, dedifferentiation and multinucleation were also reported in aging males $(25,39)$. Mitochondrial metaplasia was also described in Sertoli cells of aging testes with oxidative stress being proposed as a mechanism for these changes $(25,40)$. Sertoli cell junctions also seem to lose their characteristic appearance. In Sertoli cell of aged individuals, tight junctions, the structural basis for the blood-testis barrier, are rarer and are frequently replaced by focal contact points (18,35,37). This tight junction 
degeneration suggests the presence of a damaged Sertoli/Blood-Testis Barrier in the old individuals, compromising the specific microenvironment in which spermatogenesis occurs $(35,37)$.

\subsubsection{Germ cells}

Despite some reports suggesting that apoptosis can be the principal cause of germ cell loss (41), the mechanisms underlying the age-associated atrophy of seminiferous epithelium are still not fully understood. Impaired spermatogenesis with loss of germ cells has been observed in older men and other mammals $(14,42)$, especially during spermatocytogenesis, meiosis and spermiogenesis. This phenomena was characterized by the disarrangement of spermatogenic cells and releasing of premature spermatids from the seminiferous epithelium into the tubular lumen (35). The changes in germinal cells starts with the spermatids and progressively affects less mature cell types until it originates a complete sclerosed tubule $(13,18)$, which consists in a thickened tunica propria with abundant collagen and a few myoid cells $(18,38)$. Hence, the number of germinal cells in the seminiferous tubule usually decreases as age increases in many mammals $(15-17,43)$, resulting in a reduced diameter of seminiferous tubules (13) and epithelium vacuolization (44).

In 1986, Johnson et al. reported that older men have reduced volume of seminiferous epithelia associated with lower daily sperm production and that the efficiency of sperm production decreases with age (11). With aging, the number of spermatids (26) and spermatogonia, including A pale and A dark spermatogonia, per unit section of the testes $(45,46)$ significantly decrease. Age-related alterations of spermatogenesis in men between 65 and 93 years of age were reported by Holstein (47), and included reduction in A-dark type and A-pale type spermatogonia and arrested spermatocytes I with large 
nuclei in more than $70 \%$ of testicular sections, and many types of malformations of spermatids. Nevertheless, Johnson et al. observed that young and old men have similar numbers of A-dark and A-pale spermatogonia per unit weight of testicular parenchyma (48) and that the similar rates in germ cell degeneration at meiosis suggests that the difference in sperm production rates with age may occur in meiotic prophase, during the transition of leptotene to pachytene primary spermatocytes (48).

Morphologically, multinucleated spermatocytes (49) and spermatids $(38,50)$ in aged human testes have been reported. The formation of these kind of cells may result from the fusion of cell membranes of neighboring spermatocytes and spermatids and, as a consequence, cells undergo degeneration $(49,50)$. Other ultrastructural alterations in spermatids comprises acrosome malformation, redundant nuclear membranes, intranuclear inclusions, excessive droplet in the cytoplasm and irregular configuration of the nuclei (38). Intra-nuclear inclusions were also seen in spermatocytes and spermatogonia, as well as spirals of endoplasmic reticulum in cytoplasm (38). Morphological characteristics such as condensation of the chromatin and nuclear fragmentation in germ cells of older men support the hypothesis that the loss of germ cells observed during aging constitutes the best explanation for the low sperm counts observed in older men. On the other hand, the several ultrastructural alterations that take place may explain the higher index of teratozoospermia that these men presented.

\subsection{Alterations in basement membrane}

The basement membrane, a thin sheet-like extracellular structure that compartmentalize tissues, plays an important role in the maintenance of structural and functional integrity of tissues. In testes, the seminiferous tubule basement membrane is especially important during spermatogenesis (51). The damage of this structure has been associated with 
many testicular pathological conditions such as cryptorchidism and orchitis as well as with the aging process (52). However, literature on the morphological alterations of the basement membrane during testicular aging are contradictory. A few old studies in humans suggested that there was no alterations in this structure with aging $(11,21)$. Nevertheless, thickening and herniation of this structure with dilatation of the seminiferous tubules have been described in aged male (20,26,35), mice (13) and other mammals $(28,53)$. A statistically significant increase in the human basement membrane thickness correlated with age was found in mesenchymal (capillaries) and epithelial (testes) tissue (54). A histomorphometric study performed in testis in men from 29 to 102 years old revealed that, in cases of arrested spermatogenesis, a thickening of the basal membrane also occurs (17). Surprisingly, a more recent study (55) showed that basement membrane thickness apparently decreased with aging in men, contradicting the other previous studies. The differences showed in this study may be due to the use of immunomarking techniques using specific antibodies for the epithelial basement membranes, instead of fixing silver salts on the reticulin fibers or due to the use of measurement software on digitized microscopic images, avoiding the human error associated to the analysis.

\subsection{Modifications in vasculature}

The testicular artery is responsible for the blood supply of testis and epididymis, and several blood vessels are present in the interstitium of the seminiferous tubules. Paniagua et al. $(18,38)$ showed that the pattern of testicular involution observed in aged men was similar to the one observed after induced ischemia. This pattern is influenced by alterations in testicular perfusion caused by vascular changes, mainly in the most distal regions of artery supply. The decrease of testicular perfusion is also caused by 
atherosclerotic alterations in testicular arterioles (26). Observations of the human testicular microvasculature revealed increased coiling of interlobular arteries with age, together with many degrees of collapse of the peritubular capillary network (56). These changes are not exclusive to humans, occurring in other species with senescence, where a progressive decrease in capillary density, partial or complete occlusion of the lumen and thickening of vessel wall were observed $(57,58)$. The deficient irrigation might be an explanation for the involution of the seminiferous tubules and consequently, the lower testicular volume observed in aged male.

\subsection{Alterations in connective tissue}

In human testes, the tunica albuginea thickens and the parenchyma decreases in volume (59). In 1984, Johnson et al. (12) showed increased fibrosis and weight of the tunica albuginea with age. However, other studies revealed that tunica albuginea volume remains unchanged with age, despite the increased average width.

Lopez-Marambio and Hutson (60) found that in elderly men the tunica vaginalis became adherent to the posterior surface of the testes adjacent to the body of the epididymis, giving the appearance that the testes was retroperitoneal. Other testicular feature that appears to change with age is the testicular tunica adventitia, that becomes thicker (28). The modifications on these structures are far from being completely understood and consequently, their involvement and consequences in the decline of male reproductive capacity are still unknown.

\section{Aging and testicular (dys)fuction}

Age-dependent alterations in hormonal levels during senescence were reported and are well described in humans and other animals. However, lower androgen levels in aging 
men are not linked to a complete cessation of reproductive capacity, contrary to what happens in women with menopause and androgen deficiency is not only associated with advanced age (2).

A comparative study between the effects of age on the testicular steroidogenic activity of the Brown Norway rat and the Sprague-Dawley rat showed an age-associated decrease in serum and testicular testosterone in both models (61). A comparison of plasma testosterone levels on various species are summarized in Table 1. In human, few studies that compare endogenous steroid levels in testicular tissue from young and elderly men are available. Takahashi et al. (62) measured the concentration of nine endogenous steroids in men from 25 to 35 years old with oligozoospermia and varicocele and in men aged 61-85 years old with prostatic cancer and showed that the levels of all steroid hormones declined with age. A more recent study conducted by Carreau et al. (63) also evaluated the intra-testicular levels of steroids (pregnenolone, progesterone, DHEA, DHEAS, testosterone and estradiol) in aged men, but no significant differences between the various age groups tested were found.

In men, one of the most relevant age-related changes is the decline in testosterone levels, particularly plasma levels. Although some studies examining men of different ages failed to detect lower testosterone levels in aged males (64), the majority showed that the plasma testosterone and the fraction of testosterone biological active decline with increasing age and also that the rate of protein bound biological inactive testosterone increases (65-67). Like testosterone, dehydroepiandrosterone, dehydroepiandrosterone sulfate, cortisol, and estrone showed a significant longitudinal decline with age. On the contrary, dihydrotestosterone and pituitary gonadotropins levels rised longitudinally (68). In a review published in 2005, Harman stated that "is now reasonably clear that a significant percentage of older men have a decrease in 
testosterone and bioavailable testosterone levels, consistent with hypogonadism" (69). However, lower levels of testosterone in aged males can be multifactorial and should not be strictly associated with aging. This information highlights the need to understand how men with decreased testosterone levels would benefit from hormonal replacement. Testosterone biosynthesis occurs in testicular Leydig cells and is mainly regulated by the luteinizing hormone $(\mathrm{LH})$ secreted by the pituitary gland. In turn, LH secretion is induced by gonadotrophin releasing hormone $(\mathrm{GnRH})$ released from the hypothalamus. There is no consensus about the mechanism that cause testosterone age-related decline, but it has been associated with the three levels of the hypothalamus-pituitary-gonadal axis $(41,67)$ or with the waning of testicular function $(70)$. The decreased number of Leydig cells (20) and impaired testicular perfusion due to atherosclerosis, previously discussed, as well as reduced release of testosterone upon human Chorionic Gonadotropin (hCG) stimulation (64), support a primarily testicular cause for low testosterone levels. Additionally, it was shown that serum LH and FSH (folliclestimulating hormone) levels normally rise with aging, possible as a response to the decline in testosterone, which supports the hypothesis of secondary hypogonadism (71). In men older than 60 years it was reported that the production of LH increases with age, although the levels of FSH remain unchanged (65). In rats, serum and pituitary prolactin levels and serum estradiol levels increased with age whereas serum and pituitary FSH and LH levels decreased (72).

Other factors, besides aging, may influence the plasma and testicular levels of testosterone, including hereditary, environmental (stress, obesity), psychosocial (depression, drugs, smoking) and socio-economic factors (73). Therefore, the association of testosterone levels with age is not always linear. Furthermore, the decreased concentration of serum testosterone levels in aged male has been linked to 
andropausal symptoms such as poor libido, fatigue and deterioration of cognitive functions which can explain the infertility experienced by these couples. The hormonal variations related to age in men are summarized in Table 2.

\section{Molecular changes in aged testes}

In the past decade, several molecular mechanisms of aging have been proposed, including damage by reactive oxygen species (ROS) produced during aerobic metabolism, implicating mitochondria in the aging process (74). Indeed, mitochondrial dysfunction was already described as being involved in testicular aging (74). Aging was also associated with an increase in oxidative stress and free radical production, due to the alterations in the enzymatic activity of anti-oxidant molecules such as glutathione-stransferase (GST), an enzyme that protects cellular components from electrophilic and oxidative attack in testis $(75,76)$, glutathione peroxidase (GPx) $(76,77)$ and superoxide dismutase (SOD), especially in Leydig cells (76-78).

Several testicular age-related alterations, including the decrease in steroidogenic capacity, have also been associated to an increase in tissue inflammation. Cyclooxygenase $\square 2$ (COX2) expression is induced by cytokines and growth factors, particularly at sites of inflammation and has been associated with aged-Leydig cells phenotype since these cells express higher levels of this inducible isoenzyme $(79,80)$. Moreover, pharmacological inhibition of COX2 increases StAR expression, a Leydig cell's marker, and consequently steroidogenesis (80). However, a recent study showed that the levels of COX2 decreased, particularly in Leydig cells and macrophages, in rats with accelerated senescence when compared with the control animals (81). In long-lived mice, the expression of CD68 and CD163, macrophages markers, was reduced by half 
in testicular interstitium (81). Thus, the actual role of inflammation in reproductive aging is poorly understood and needs further investigation.

The smooth muscle located in tunica albuginea is responsible for testicular capsular contraction that is involved in the transport of non-motile sperm to the epididymis. With aging, the capsule gets thicker, as already explained above, and the response to norepinephrine and prostaglandin becomes progressively higher, suggesting that neurohumoral agents may have an important role in the maintenance of testicular capsular contractions (82).

The main molecular age-related alterations identified in the different testicular cells are described below and summarized in Table 3 .

\subsection{Leydig cells}

The aging Leydig cells are characterized by the reduced ability to produce testosterone in response to LH (73). Several cellular changes have been identified in the steroidogenic pathway of aged Leydig cells in human that result in the reduction of testosterone production. These alterations are not exclusive to the aging process and might be influenced by other variables such as mood changes, fatigue, decreased lean body mass, reduced mineral bone density, increased visceral fat and metabolic syndrome (73).

Aging modulates the expression of genes responsible for cGMP production and degradation, which results in an increase in cGMP in Leydig cells (83). Additionally, several studies suggested a reduction in cAMP-signaling in aged cells (84), which together with the elevation of cGMP may be an explanation for the reduction in testosterone levels since both signaling pathways are involved in testosterone production. 
Previous investigations also reported alterations in the expression profiles of 45 genes (85) and a decrease in LH receptor levels (72) in aged rats. The secretion of the insulinlike factor 3 (INSL3), a small peptide hormone secreted by mature Leydig cells, is an important indicator of the differentiation status and the number of Leydig cells present in testes. The levels of this peptide hormone decline gradually with aging reflecting the functional capacity of this type of cells. Supporting this data, in old rats INSL3 expression also seems to be down-regulated with age $(86,87)$. The expression levels of LH receptors in Leydig cells also decreases with age in Fisher 344 rats (72). The response of Leydig cells to LH depends not only on the number of receptors and the circulating concentration of glucocorticoids, but also on $11 \beta$-HSD activity (88). With increasing age, the expression of this enzyme is reduced and consequently, a reduction in testosterone production is observed (88). The aging impact in the number and volume of Leydig cells and the molecular alterations described in this section explain the reduction in testosterone levels often observed in older men. However, it is important to keep in mind that these alterations may result from a combination of elements, including environmental factors that can affect the testes and, particularly, this type of cells.

\subsection{Sertoli cells}

Sertoli cells secretions and metabolites are crucial for the normal occurrence of spermatogenesis. The expression of some of these products is dependent on an intricate network of signaling molecules and hormones $(30,89)$.

It has been reported that aging is able to alter the production of some important secretions by the Sertoli cell and even its molecular composition. Indeed, the synthesis and secretion of two of the major products of Sertoli cells, transferrin and cathepsin $\mathrm{L}$ 
(also called cyclic protein-2, CP-2) is affected in older individuals, while that of others, such as sulphated glycoprotein-2 (SGP-2, also called Clusterin), remains unaffected $(37,42,90)$. Transferrin is a major secretory protein of Sertoli cells, being involved in the transport of iron in cells of the seminiferous epithelium. In brown Norway rats, the total testicular content of transferrin mRNA remained unchanged up to 18 months of age, but dramatically increased by the age of 2 years. In opposition, the mRNA CP-2 testicular content of older rats was shown to be decreased $(42,90)$. The stage-specific expression of CP-2 in the seminiferous epithelium suggested that the presence of the active cathepsin L facilitates the intense reorganization of the seminiferous epithelium during germ cell development (91), enhancing the degradation of dying or dead germ cells (90). These age-associated alterations of transferrin and CP-2/cathepsin L levels in aged rats led to the suggestion that age-related changes in Sertoli cell gene expression reflect a primary dysfunction of aging and not an indirect effect due to germ cell loss (42).

Moreover, age-associated alterations in the cytoskeletal components of Sertoli cells, namely F-actin, vimentin and cytokeratin, were described in aged BDF1 mice. In old mice, F-actin was distributed at the inter-Sertoli cells junctions and at the luminal portion of the Sertoli cell cytoplasm, while in young mice it was only detectable at the junctions between adjoining Sertoli cells (39). Similarly, vimentin was recognized only around the nucleus in Sertoli cell of old animals, and not in the Sertoli cell trunk as seen in young mice. Instead, in old mice testes, sheet-like organizations of vimentin were detected near the luminal surface parallel to the basement membrane (39). On the other hand, cytokeratin expression pattern was dramatically altered in the mice Sertoli cells. Up until 27 months of age, no cytokeratin expression was detected in Sertoli cells. Only in older mice, which exhibited thinner seminiferous epithelia, the expression of 
cytokeratin was consistently detected within the Sertoli cell cytoplasm, being one of the most characteristic occurrences of age-associated changes in Sertoli cells (39).

In men, serum inhibin levels decline with aging, with older individuals presenting significantly lower serum concentrations of this glycoprotein already at the age of 40 (92). Inhibin is a hormonal glycoprotein secreted by Sertoli cells in response to the stimulation by FSH, which negatively feedbacks on the pituitary gland to specifically suppress the production and secretion of FSH. This hormone is often used as a functionality marker for Sertoli cells and for the impairment of spermatogenesis (93). The decrease observed in the secretion of inhibin by Sertoli cells led to the suggestion that the testicular endocrine functions decline as soon as the fourth decade of life, and that Sertoli cell function declines earlier than that of other somatic testicular cells (92). In fact, the expression of the receptor for the hormone serotonin, an important player on germ cell-Sertoli cell interactions (94), is lost in Sertoli cells from rats older than 24 months (40), further confirming this suggestion.

Additionally, age-associated accumulation of intracellular amyloid fibrils in Sertoli cells has also been reported (95). This accumulation is concurrent with the buildup of lipofuscin-loaded lysosomes, as well as of damaged mitochondria, in Sertoli cells. The activity of the enzymes that degrade lipofuscin and damaged mitochondria (by autophagy) is diminished, leading to their accumulation. Dysfunctional mitochondria produce more ROS and lipofuscin accumulation sensitizes cells to ROS-induced damage, which then becomes a self-amplifying, vicious cycle in these cells (96).

\subsection{Germ cells}

As explained in Section 4.1.3., with aging the number of germ cells in the seminiferous tubule decreases in humans and most mammals $(15-17,43)$ and several ultrastructural 
alterations take place. Indeed, spermatogenesis gradually decreases in older men (97). To investigate whether this reduction resulted from apoptotic events, Barnes et al. studied mice from different age groups and observed that apoptotic cell death of testicular germ cells does not seem to be altered with age (98). However, an increase in apoptotic metaphase spermatocytes at tubule stage XIV in mice with 24 months of age when compared with 6 months old mice was observed (98).

Like Leydig cells, the decreased number in germinal cells in aged testes was accompanied by changes in gene expression profile, particularly in the expression of spermatogonia markers (99). An investigation conducted in mouse that compared the gene expression in four age groups $(6,21,60$ days and 8 months) revealed that certain genes were specifically expressed in older mice and some genes were up- (Gpr116, Gpr146, Gpr56. Grb2, Icam1, Lims1, Lin52, SELP and Trio) and down-regulated (Gpr107, Tyrobp, Smad4, Ms4a7 and Mrc1) (100). Beside, 16 proteins were identified as dramatically increased and 21 were decreased in aged human testes compared to the young ones, especially proteins involved in oxidative stress (97). These proteins can constitute valuable markers of reproductive aging.

\section{Summary and future perspectives}

Advanced paternal age is a common phenomenon in modern societies. Social-economic factors and personal choices contribute to this tendency. This evidence highlights the need to discuss and investigate the effect of advanced paternal age in the male reproductive system, in semen parameters and the impact on the offspring's health. As we described in the above sections, the testes, as all the other systems in the body, suffer several complex alterations that might be an explanation for the reproductive decline observed in men. Aged testes undergo profound histological and morphological 
alterations, including tissue atrophy, leading to a reduced functionality. In addition, several molecular alterations were reported in all testicular cell types. These age-related changes are usually so small that men are capable to be fertile until old age. However, this delay in parenthood may have negative consequences to the descendants and the real impact of those age-related alterations in men fertility potential are still unknown. Additionally, the impact of age is not exclusive to humans but were also present in many mammalian species, reflecting the transversality of this phenomenon. Some of them, such as mice and rat, can be used as animal models to study the aging phenomenon. In fact, the Brown Norway rat is already identified as an excellent model for the study of the male reproductive aging due to the similar alterations that appear with age in humans (101). Finally, some important questions remain unanswered and should be the focus of future research in this field.

- Are the alterations in the composition of cell populations the main responsible for the decreased testicular volume with age, or this happens only due to an increased basement membrane and tunica albuginea thickness?

- Are the levels of steroid hormones the key to these changes or are their clinical impact irrelevant?

- Is the decrease in the amount of different cell types a result of the molecular changes that occur or they precede them?

- Are the changes in testicular vascularization the main responsible for most of the testicular age-related alterations?

These and other questions should be investigated and the identification of the sequence of events might be important to better understand this phenomenon. Indeed, the comprehension of the mechanisms of testicular aging and the reproductive decline can 
be very useful to better understand some cases of male infertility and to finally address the question - How old is too old to be a father?.

\section{Funding}

This work was supported by FEDER Funds through Competitiveness and Internationalization Operational Program - COMPETE 2020 and by National Funds through FCT-Foundation for Science and Technology under the project PTDB/BBBBQB/3804/2014. This study was also supported by Institute for Biomedicine - iBiMED (UID/BIM/04501/2013) and by individual grant from FCT of the Portuguese Ministry of Science and Higher Education to JVS (SFRH/BPD/123155/2016). 


\section{References}

1. Sharma R, Agarwal A, Rohra VK, Assidi M, Abu-Elmagd M, Turki RF. Effects of increased paternal age on sperm quality, reproductive outcome and associated epigenetic risks to offspring. Reprod Biol Endocrinol. 2015;13:35. doi:10.1186/s12958-015-0028-x.

2. Tenover JS. Declining testicular function in aging men. Int J Impot Res. 2003;15(4):S3-S8. doi:10.1038/sj.ijir.3901029.

3. Bastos P, Freitas MJ, Gomes A, Vitorino R, Fardilha M. Unravelling the Power of Omics for the Infertile Ageing Male. Curr Pharm Des. 2017;23:1-19. doi:10.2174/1381612822666161018155247.

4. Belloc S, Hazout A, Zini A, et al. How to overcome male infertility after 40: Influence of paternal age on fertility. Maturitas. 2014;78(1):22-29. doi:10.1016/j.maturitas.2014.02.011.

5. Herati AS, Zhelyazkova BH, Butler PR, Lamb DJ. Age-related alterations in the genetics and genomics of the male germ line. Fertil Steril. 2017;107(2):319-323. doi:10.1016/j.fertnstert.2016.12.021.

6. Handelsman DJ, Staraj S. Testicular size: the effects of aging, malnutrition, and illness. J Androl. 1985;6(3):144-151. doi:10.1002/j.1939-4640.1985.tb00830.x.

7. Arenas MI, Bethencourt FR, Fraile B, Paniagua R. Immunocytochemical and quantitative study of the tunica albuginea testis in young and ageing men. Histochem Cell Biol. 1997;107(6):469-477. doi:10.1007/s004180050134.

8. Well D, Yang H, Houseni M, et al. Age-Related Structural and Metabolic Changes in the Pelvic Reproductive End Organs. Semin Nucl Med. 2007;37(3):173-184. doi:10.1053/j.semnuclmed.2007.01.004.

9. Mahmoud AM, Goemaere S, El-Garem Y, Van Pottelbergh I, Comhaire FH, Kaufman JM. Testicular Volume in Relation to Hormonal Indices of Gonadal Function in Community-Dwelling Elderly Men. J Clin Endocrinol Metab. 2003;88(1):179-184. doi:10.1210/jc.2002-020408.

10. Yang H, Chryssikos T, Houseni M, et al. The effects of aging on testicular volume and glucose metabolism: An investigation with ultrasonography and FDG-PET. Mol Imaging Biol. 2011;13(2):391-398. doi:10.1007/s11307-0100341-x.

11. Johnson L, Petty CS, Neaves WB. Age-related variations in seminuferous tubules in men-A stereologic evaluation. $J$ Androl. 1986;7:316-322. doi:10.1002/j.19394640.1986.tb00939.x.

12. Johnson L, Petty CS, Neaves WB. Influence of age on sperm production and testicular weights in men. $J$ Reprod Fertil. 1984;70(1):211-218.

13. Gosden RG, Richardson DW, Brown N, Davidson DW. Structure and gametogenic potential of seminiferous tubules in ageing mice. J Reprod Fertil. 1982;64(1):127-133. ISBN:0022-4251 (Print)r0022-4251 (Linking).

14. Wolf KN, Wildt DE, Vargas A, et al. Age-dependent changes in sperm production, semen quality, and testicular volume in the black-footed ferret (Mustela nigripes). Biol Reprod. 2000;63(1):179-187. doi:10.1095/biolreprod63.1.179.

15. Horn R, Pastor LM, Moreno E, Calvo A, Canteras M, Pallares J. Morphological and morphometric study of early changes in the ageing golden hamster testis. $J$ Anat. 1996;188:109-117.

16. Obregon EB, Ramirez O. Ageing and testicular function in Octodon degus. Andrologia. 1997;29(6):319-326. doi:10.1111/j.1439-0272.1997.tb00325.x. 
17. Dakouane M, Bicchieray L, Bergere M, Albert M, Vialard F, Selva J. A histomorphometric and cytogenetic study of testis from men 29-102 years old. Fertil Steril. 2005;83(4):923-928. doi:10.1016/j.fertnstert.2004.12.005.

18. Paniagua R, Nistal M, Sáez FJ, Fraile B. Ultrastructure of the aging human testis. J Electron Microsc Tech. 1991;19(2):241-260. doi:10.1002/jemt.1060190209.

19. Neaves WB, Johnson L, Petty CS. Age-related change in numbers of other interstitial cells in testes of adult men: evidence bearing on the fate of Leydig cells lost with increasing age. Biol Reprod. 1985;33(1):259-269.

20. Neaves WB, Johnson L, Porter JC, Parker CR, Petty CS. Leydig Cell Numbers, Daily Sperm Production, and Serum Gonadotropin Levels in Aging Men. J Clin Endocrinol Metab. 1984;59(4):756-763. doi:10.1210/jcem-59-4-756.

21. Honoré LH. Ageing changes in the human testis: a light-microscopic study. Gerontology. 1978;24(1):58-65.

22. Ichihara I, Kawamura H, Pelliniemi LJ. Ultrastructure and morphometry of testicular Leydig cells and the interstitial components correlated with testosterone in aging rats. Cell Tissue Res. 1993;271(2):241-255. doi:https://doi.org/10.1007/BF00318610.

23. Chen H, Hardy MP, Huhtaniemi I, Zirkin BR. Age $\square$ related decreased Leydig Cell testosterone production in the Brown Norway rat. J Androl. 1994;15(6):551557. doi:10.1002/j.1939-4640.1994.tb00498.x.

24. Neves BVD, Lorenzini F, Veronez D, Miranda EP de, Neves GD, Fraga R de. Numeric and volumetric changes in Leydig cells during aging of rats. Acta Cir Bras. 2017;32(10):807-815. doi:10.1590/s0102-865020170100000002.

25. Paniagua R, Amat P, Nistal M, Martin A. Ultrastructure of Leydig cells in human ageing testes. J Anat. 1986;146:173-183.

26. Sasano N, Ichijo S. Vascular Patterns of the Human Testis with Special Reference to Its Senile Changes. Tohoku J exp Med. 1969;99:269-280.

27. Miquel J, Lundgren PR, Johnson JE. Spectrophotofluorometric and electron microscopic study of lipofuscin accumulation in the testis of aging mice. $J$ Gerontol. 1978;33(1):3-19.

28. Elcock LH, Schoning P. Age-related changes in the cat testis and epididymis. Am $J$ Vet Res. 1984;45(11):2380-2384.

29. Johnson L, Neaves WB. Age-Related Changes in the Leydig Cell Population, Seminiferous Tubules, and Sperm Production in Stallions. Biol Reprod. 1981;24(3):703-712.

30. Oliveira PF, Alves MG. Sertoli Cell and Germ Cell Differentiation. In: Sertoli Cell Metabolism and Spermatogenesis. Cham: Springer International Publishing; 2015:25-39. doi:10.1007/978-3-319-19791-3_4.

31. Oliveira PF, Alves MG. The Sertoli Cell at a Glance. In: Sertoli Cell Metabolism and Spermatogenesis. Cham: Springer International Publishing; 2015:3-13. doi:10.1007/978-3-319-19791-3_2.

32. Cummins JM, Jequier AM, Kan R. Molecular biology of human male infertility: Links with aging, mitochondrial genetics, and oxidative stress? Mol Reprod Dev. 1994;37(3):345-362. doi:10.1002/mrd.1080370314.

33. Johnson L, Zane R, Petty C, Neaves B. Quantification of the human Sertoli cell population: its distribution, relatin to germ cell numbers and age-related decline. Biol Reprod. 1984;31(4):785-795.

34. Petersen PM, Pakkenberg B. Stereological Quantitation of Leydig and Sertoli Cells in the Testis From Young and Old Men. Image Anal Stereol. 2000;19:215218. doi:10.5566/ias.v19.p215-218. 
35. Jiang H, Zhu WJ, Li J, Chen QJ, Liang WB, Gu YQ. Quantitative histological analysis and ultrastructure of the aging human testis. Int Urol Nephrol. 2014;46(5):879-885. doi:10.1007/s11255-013-0610-0.

36. Humphreys PN. The histology of the testis in aging and senile rats. Exp Gerontol. 1977;12(1-2):27-34. doi:10.1016/0531-5565(77)90029-8.

37. Levy S, Serre V, Hermo L, Robaire B. The effects of aging on the seminiferous epithelium and the blood-testis barrier of the Brown Norway rat. J Androl. 1999;20(3):356-365. doi:10.1002/j.1939-4640.1999.tb02529.x.

38. Paniagua R, Nistal M, Amat P, Rodriguez MC, Martin A. Seminiferous tubule involution in elderly men. Biol Reprod. 1987;36(4):939-947.

39. Tanemura K, Kurohmaru M, Kuramoto K, Matsumoto M, Hayashi Y. Agerelated changes in cytoskeletal components of the BDF1 mouse Sertoli cell. Tissue Cell. 1994;26(3):447-455.

40. Rehman K ur, Carrier S. Aging and the Male Gonads. Geriatr Aging. 2003;6(1):34-36.

41. Gunes S, Hekim GNT, Arslan MA, Asci R. Effects of aging on the male reproductive system. J Assist Reprod Genet. 2016;33(4):441-454. doi:10.1007/s10815-016-0663-y.

42. Wright WW, Fiore C, Zirkin BR. The effect of aging on the seminiferous epithelium of the brown Norway rat. $J$ Androl. 1993;14(2):110-117. doi:10.1002/j.1939-4640.1993.tb01661.x.

43. Suzuki N, Withers HR. Exponential decrease during aging and random lifetime of mouse spermatogonial stem cells. Science (80- ). 1978;202(4373):1214-1215. doi:10.1126/science.725597.

44. $\mathrm{Xu} \mathrm{Y,} \mathrm{Li} \mathrm{J,} \mathrm{Liang} \mathrm{W,} \mathrm{Zhu} \mathrm{W.} \mathrm{Evaluation} \mathrm{on} \mathrm{Changes} \mathrm{of} \mathrm{Testicular} \mathrm{Histology} \mathrm{in}$ Aging Men. J Reprod Contracept. 2013;24(4):199-204. doi:10.7669/j.issn.10017844.2013.04.0199.

45. Morales E, Pastor LM, Horn R, et al. Effect of ageing on the proliferation and apoptosis of testicular germ cells in the Syrian hamster Mesocricetus auratus. Reprod Fertil Dev. 2003;15(1-2):89-98. doi:10.1071/RD02071.

46. Nistal M, Codesal J, Paniagua R, Santamaria L. Decrease in the number of human Ap and Ad spermatogonia and in the Ap/ Ad ratio with advancing age. New data on the spermatogonial stem cell. $J$ Androl. 1987;8(2):64-68. doi:10.1002/j.1939-4640.1987.tb00950.x.

47. Holstein AF. Spermatogenesis in the aged-a borderland between normal and pathologic anatomy. Urologe A. 1986;25(3):130-137.

48. Johnson L, Nguyen HB, Petty CS, Neaves WB. Quantification of human spermatogenesis: germ cell degeneration during spermatocytogenesis and meiosis in testes from younger and older adult men. Biol Reprod. 1987;37(3):739-747. ISBN:0006-3363 (Print)r0006-3363 (Linking).

49. Miething A. Multinucleated spermatocytes in the aging human testis: formation, morphology, and degenerative fate. Andrologia. 1993;25(6):317-323. doi:10.1111/j.1439-0272.1993.tb02733.x.

50. Nistal M, Codesal J, Paniagua R. Multinucleate spermatids in aging human testes. Arch Androl. 1986;16(2):125-129.

51. Kahsai TZ, Enders GC, Gunwar S, et al. Seminiferous Tubule Basement Membrane. J Biol Chem. 1997;272(27):17023-17032.

52. Omar S, Banerjee P, Deb S. Evaluation of basement membrane thickness of somniferous tubules in cryptorchid tests. J Evid Based Med Healthc. 2014;1(5):238-244. 
53. Fukuda T, Kikuchi M, Kurotaki T, Oyamada T, Yoshikawa H, Yoshikawa T. Age-related changes in the testes of horses. Equine Vet J. 2001;33(1):20-25. doi:10.2746/042516401776767449.

54. Xi YP, Nette EG, King DW, Rosen M. Age-related changes in normal human basement membrane. Mech Ageing Dev. 1982;19(4):315-324.

55. Pop OT, Cotoi CG, Pleşea IE, et al. Histological and ultrastructural analysis of the seminiferous tubule wall in ageing testis. Rom J Morphol Embryol. 2011;52:241-248.

56. Takizawa T, Hatakeyama S. Age-associated changes in microvasculature of human adult testis. Acta Pathol Jpn. 1978;28(4):541-554. doi:10.1111/j.14401827.1978.tb00894.x.

57. Auroux M, Nawar NN, Rizkalla N. Testicular aging: vascularization and gametogenesis modifications in the Wistar rat. Arch Androl. 1985;14(2-3):115121. doi:10.3109/01485018508988286.

58. Mahmood IM. Histological changes in testicular tissue with age. Tikrit J Pure Sci. 2008;13(3):11-14.

59. Johnson L. Evaluation of the human testis and its age-related dysfunction. Prog Clin Biol Res. 1989;302:35-60-7.

60. Lopez-Marambio FA, Hutson JM. The relationship between the testis and tunica vaginalis changes with age. J Pediatr Surg. 2015;50(12):2075-2077. doi:10.1016/j.jpedsurg.2015.08.032.

61. Zirkin BR, Santulli R, Strandberg JD, Wright WW, Ewing LL. Testicular Steroidogenesis in the Aging Brown Norway Rat. J Androl. 1993;14(2):118-123. doi:10.1002/j.1939-4640.1993.tb01663.x.

62. Takahashi J, Higashi Y, Lanasa JA, et al. Studies of the Human Testis. XVIII. Simultaneous Measurement of Nine Intratesticular Steroids: Evidence for Reduced Mitochondrial Function in Testis of Elderly Men. J Clin Endocrinol Metab. 1983;56(6):1178-1187. doi:10.1210/jcem-56-6-1178.

63. Carreau S, Bourguiba S, Marie E. Testicular and blood steroid levels in aged men. Reprod Biol. 2004;4(3):299-304.

64. Harman SM, Tsitouras PD. Reproductive Hormones in Aging Men. I. Measurement of Sex Steroids, Basal Luteinizing Hormone, and Leydig Cell Response to Human Chorionic Gonadotropin. J Clin Endocrinol Metab. 1980;51(1):35-40. doi:10.1210/jcem-51-1-35.

65. Mauss J. Exo- and endocrine testicular function in the aging man. Fortschr Med. 1975;93(31):1543-1544.

66. Davidson JM, Chen JJ, Crapo L, Gray GD, Greenleaf WJ, Catania JA. Hormonal changes and sexual function in aging men. $J$ Clin Endocrinol Metab.

1983;57(1):71-77. doi:10.1210/jcem-57-1-71.

67. Wu FCW, Tajar A, Pye SR, et al. Hypothalamic-pituitary-testicular axis disruptions in older men are differentially linked to age and modifiable risk factors: The European male aging study. J Clin Endocrinol Metab. 2008;93(7):2737-2745. doi:10.1210/jc.2007-1972.

68. Feldman HA, Longcope C, Derby CA, et al. Age trends in the level of serum testosterone and other hormones in middle-aged men: longitudinal results from the Massachusetts male aging study. J Clin Endocrinol Metab. 2002;87(2):589598. doi:10.1210/jcem.87.2.8201.

69. Harman SM. Testosterone in older men after the Institute of Medicine Report: Where do we go from here? Climacteric. 2005;8(2):124-135. doi:10.1080/13697130500118001. 
70. Golan R, Scovell JM, Ramasamy R. Age-related Testosterone Decline is due to Waning of Both Testicular and Hypothalamic-Pituitary Function. Aging Male. 2015;18(3):201-204. doi:10.3109/13685538.2015.1052392.

71. Beattie MC, Adekola L, Papadopoulos V, Chen H, Zirkin BR. Leydig cell aging and hypogonadism. Exp Gerontol. 2015;68:87-91. doi:10.1016/j.exger.2015.02.014.

72. Amador A, Steger RW, Bartke A, et al. Testicular LH receptors during aging in Fisher 344 rats. J Androl. 1985;6(1):61-64. doi:10.1002/j.19394640.1985.tb00816.x.

73. Wang Y, Chen F, Ye L, Zirkin B, Chen H. Steroidogenesis in Leydig cells: effects of aging and environmental factors. Reproduction. 2017;154(4):R111R122. doi:10.1530/REP-17-0064.

74. Amaral S, Amaral A, Ramalho-Santos J. Aging and male reproductive function: A mitochondrial perspective. Front Biosci (Schol Ed). 2013;5:181-197.

75. Mueller A, Hermo L, Robaire B. The effects of aging on the expression of glutathione S-transferases in the testis and epididymis of the Brown Norway rat. J Androl. 1998;19(4):450-465. doi:10.1002/j.1939-4640.1998.tb02039.x.

76. Salomon TB, Hackenhaar FS, Almeida AC, et al. Oxidative stress in testis of animals during aging with and without reproductive activity. Exp Gerontol. 2013;48(9):940-946. doi:10.1016/j.exger.2013.06.010.

77. Cao L, Leers-Sucheta S, Azhar S. Aging alters the functional expression of enzymatic and non-enzymatic anti-oxidant defense systems in testicular rat Leydig cells. J Steroid Biochem Mol Biol. 2004;88(1):61-67. doi:10.1016/j.jsbmb.2003.10.007.

78. Vázquez-Memije ME, Capin R, Tolosa A, El-Hafidi M. Analysis of ageassociated changes in mitochondrial free radical generation by rat testis. Mol Cell Biochem. 2008;307(1-2):23-30. doi:10.1007/s11010-007-9580-9.

79. Chen H, Luo L, Liu J, Zirkin BR. Cyclooxygenases in Rat Leydig Cells: Effects of Luteinizing Hormone and Aging. Endocrinology. 2007;148(2):735-742. doi:10.1210/en.2006-0925.

80. Wang X, Shen C-L, Dyson MT, et al. Cyclooxygenase-2 Regulation of the AgeRelated Decline in Testosterone Biosynthesis. Endocrinology. 2005;146(10):4202-4208. doi:10.1210/en.2005-0298.

81. Matzkin ME, Miquet JG, Fang Y, et al. Alterations in oxidative, inflammatory and apoptotic events in short-lived and long-lived mice testes. Aging (Albany NY). 2016;8(1):95-110.

82. Horowitz AM, Davis JR. Effect of ageing on the response of the rat isolated testicular capsule to norepinephrine, acetylcholine and prostaglandins. Mech Ageing Dev. 1979;11(5-6):393-401. doi:https://doi.org/10.1016/00476374(79)90015-0.

83. Baburski AZ, Sokanovic SJ, Andric SA, Kostic TS. Aging has the opposite effect on cAMP and cGMP circadian variations in rat Leydig cells. J Comp Physiol B. 2017;187(4):613-623. doi:10.1007/s00360-016-1052-7.

84. Chen H, Ge R-S, Zirkin BR. Leydig cells: From stem cells to aging. Mol Cell Endocrinol. 2012;100(2):130-134. doi:10.1016/j.pestbp.2011.02.012.Investigations.

85. Chen H, Irizarry RA, Luo L, Zirkin BR. Leydig cell gene expression: Effects of age and caloric restriction. Exp Gerontol. 2004;39(1):31-43. doi:10.1016/j.exger.2003.09.021.

86. Paust HJ, Wessels J, Ivell R, Mukhopadhyay AK. The expression of the 
RLF/INSL3 gene is reduced in Leydig cells of the aging rat testis. Exp Gerontol. 2002;37(12):1461-1467. doi:10.1016/S0531-5565(02)00098-0.

87. Ivell R, Wade JD, Anand-Ivell R. INSL3 as a Biomarker of Leydig Cell Functionality. Biol Reprod. 2013;88(6):147-147.

doi:10.1095/biolreprod.113.108969.

88. Koeva Y, Bakalska M, Atanassova N, Georgieva K, Davidoff M. Age-related changes in the expression of 11 beta-hydroxysteroid dehydrogenase type 2 in rat Leydig cells. Folia Histochem Cytobiol. 2009;47(2):281-287. doi:10.2478/v10042-009-0021-3.

89. Oliveira PF, Cheng CY, Alves MG. Emerging Role for Mammalian Target of Rapamycin in Male Fertility. Trends Endocrinol Metab. 2017. doi:10.1016/j.tem.2016.12.004.

90. Kim GH, Wright WW. A comparison of the effects of testicular maturation and aging on the stage-specific expression of CP-2/cathepsin L messenger ribonucleic acid by Sertoli cells of the Brown Norway rat. Biol Reprod. 1997;57:1467-1477. ISBN:0006-3363 (Print).

91. Erickson-Lawrence M, Zabludoff SD, Wright WW. Cyclic protein 2, a secretory product of rat Sertoli cells, is the proenzyme form of cathepsin L. Mol Endocrinol. 1991;5(12):1789-1798. doi:10.1210/mend-5-12-1789.

92. Haji M, Tanaka S, Nishi Y, et al. Sertoli cell function declines earlier than leydig cell function in aging japanese men. Maturitas. 1994;18(2):143-153. doi:http://dx.doi.org/10.1016/0378-5122(94)90052-3.

93. Mędraś M, Trzmiel-Bira A, Jóźków P, Terpiłowski Ł, Zagocka E, SicińskaWerner T. Inhibin B and FSH as markers of Sertoli cell function in impaired spermatogenesis. Endokrynol Pol. 2010;61(6):695-698.

94. Syed V, Hecht NB. Selective loss of Sertoli cell and germ cell function leads to a disruption in sertoli cell-germ cell communication during aging in the Brown Norway rat. Biol Reprod. 2001;64(1):107-112. ISBN:0006-3363 (Print).

95. Bohl J, Steinmetz H, Störkel S. Age-related accumulation of congophilic fibrillar inclusions in endocrine cells. Virchows Arch A Pathol Anat Histopathol. 1991;419(1):51-58. doi:10.1007/BF01600152.

96. Desai N, Sabanegh E, Kim T, Agarwal A. Free Radical Theory of Aging: Implications in Male Infertility. Urology. 2010;75(1):14-19. doi:10.1016/j.urology.2009.05.025.

97. Liu X, Liu FJ, Jin SH, et al. Comparative proteome analysis of human testis from newborn, young adult, and aged men identified spermatogenesis-associated proteins. Electrophoresis. http://www.ncbi.nlm.nih.gov/pubmed/26031402. Published August 1, 2015. Accessed October 27, 2017.

98. Barnes CJ, Covington BW, Cameron IL, Lee M. Effect of aging on spontaneous and induced mouse testicular germ cell apoptosis. Aging (Milano). 1998;10(6):497-501. doi:https://doi.org/10.1007/BF03340164.

99. Giassetti MI, Goissis MD, Moreira PV, de Barros FR, Assumpção ME, Visintin JA. Effect of age on expression of spermatogonial markers in bovine testis and isolated cells. Anim Reprod Sci. 2016;170:68-74.

doi:10.1016/j.anireprosci.2016.04.004.

100. Kokkinaki M, Lee T, He Z, et al. Age affects gene expression in mouse spermatogonial stem/ progenitor cells. Reproduction. 2010;139(6):1011-1020. doi:10.1530/REP-09-0566.Age.

101. Wang C, Hikim AS, Ferrini M, et al. Male reproductive ageing: using the brown Norway rat as a model for man. Novartis Found Symp. 2002;242:82-95-7. 
http://www.ncbi.nlm.nih.gov/pubmed/11855696. Accessed October 27, 2017.

102. Rigaudiere N, Pelardy G, Robert A, Delost P. Changes in the concentration of testosterone and androstenedione in the plasma and testis of the guinea-pig from birth to death. J Reprod Fertil. 1976;48(2):291-300.

103. Winters SJ, Takahashi J. Estrogens and Cytosolic Estrogen Receptors in Aged Male. J Androl. 1983;4(3):171-174. doi:10.1002/j.1939-4640.1983.tb00746.x.

104. Kinoshita Y, Higashi Y, Winters SJ, Oshima H, Troen P. An analysis of the agerelated decline in testicular steroidogenesis in the rat. Biol Reprod. 1985;32(2):309-314. doi:10.1095/biolreprod32.2.309.

105. Machida T, Yonezawa Y, Noumura T. Age-associated changes in plasma testosterone levels in male mice and their relation to social dominance or subordinance. Horm Behav. 1981;15(3):238-245. doi:10.1016/0018506X(81)90013-1.

106. Nelson JF, Latham KR, Finch CE. Plasma testosterone levels in C57BL/6J male mice: effects of age and disease. Acta Endocrinol (Copenh). 1975;80(4):744-752. doi:10.1530/ACTA.0.0800744.

107. Martin DE, Swenson RB, Collins DC. Correlation of serum testosterone levels with age in male chimpanzees. Steroids. 1977;29(4):471-481.

108. Deslypere JP, Vermeulen A. Leydig cell function in normal men: effect of age, life-style, residence, diet, and activity. J Clin Endocrinol Metab. 1984;59(5):955962. doi:10.1210/jcem-59-5-955.

109. Lewis JG, Ghanadian R, Chisholm GD. Serum 5alpha-dihydrotestosterone and testosterone changes with age in man. Acta Endocrinol (Copenh). 1976;82(2):444-448. doi:10.1530/acta.0.0820444.

110. Ramezani Tehrani F, Mansournia MA, Solaymani-Dodaran M, Minooee S, Azizi F. Serum variations of anti-mullerian hormone and total testosterone with aging in healthy adult Iranian men: A population-based study. PLoS One. 2017;12(7):e0179634. doi:10.1371/journal.pone.0179634.

111. Chong YH, Pankhurst MW, McLennan IS. The testicular hormones AMH, InhB, INSL3, and testosterone can be independently deficient in older men. Journals Gerontol - Ser A Biol Sci Med Sci. 2017;72(4):548-553. doi:10.1093/gerona/glw143.

112. Kaur S, Gill SS. Effect of aging on testicular epoxide hydrolase and glutathiones-transferase activities in mice. Toxicol Lett. 1986;30(2):113-120. doi:10.1016/0378-4274(86)90093-7.

113. Amaral S, Mota P, Rodrigues AS, Martins L, Oliveira PJ, Ramalho-Santos J. Testicular aging involves mitochondrial dysfunction as well as an increase in UCP2 levels and proton leak. FEBS Lett. 2008;582(30):4191-4196. doi:10.1016/j.febslet.2008.11.020.

114. Sokanovic SJ, Janjic MM, Stojkov NJ, et al. Age related changes of cAMP and MAPK signaling in Leydig cells of Wistar rats. Exp Gerontol. 2014;58:19-29. doi:10.1016/j.exger.2014.07.004.

115. Yuan Q, Guo QS, Cornwall GA, Xu C, Wang YF. Age-dependent expression of the cystatin-related epididymal spermatogenic (Cres) gene in mouse testis and epididymis. Asian J Androl. 2007;9(3):305-311. doi:10.1111/j.17457262.2007.00260.x. 
Figure 1 - Testes. Cross-section showing the location of the seminiferous tubules, the vas deferens and the epididymis as well as the tunica albuginea. Schematic cross-section of a testicular tubules illustrating the germ cells at different stages of maturation within a somatic Sertoli cell. Leydig cells and vasculature are present in the interstitium. Major morphological, cellular and ultrastructural alterations associated with age in testis are indicated. 
Table 1- Comparison of the levels of plasma testosterone $(\mathrm{ng} / \mathrm{ml})$ in various species from infancy to senescence.

\begin{tabular}{lllllll}
\hline Specie & Infancy & Puberty & Adulthood & Senescence & Assay & Reference \\
\hline Guinea-pig & 0.8 & 6.1 & 3.6 & $>2.2$ & GLC & $(102)$ \\
\hline Rat & - & 1.77 & - & 0.83 & RIA & $(103)$ \\
& & 3.7 & $2.5-2.2$ & 1.1 & RIA & $(72)$ \\
& 3.2 & 1.8 & 2.2 & 1.1 & RIA & $(104)$ \\
\hline Mice & & & 5.2 & 1.8 & RIA & $(105)$ \\
& & & 1.12 & 1.17 & RIA & $(106)$ \\
\hline Chimpanzee & 0.13 & 1.78 & 3.97 & & RIA & $(107)$ \\
\hline
\end{tabular}

Note: GLC, gas-liquid chromatography; RIA, radioimmunoassay. 
Table 2 - Age-related changes in hormonal levels in human.

\begin{tabular}{|c|c|c|c|c|}
\hline Hormone & $\begin{array}{l}\text { Younger } \\
\text { men }\end{array}$ & $\begin{array}{l}\text { Elderly } \\
\text { men }\end{array}$ & $\begin{array}{l}\text { Age groups } \\
\text { (years) }\end{array}$ & Ref. \\
\hline \multicolumn{5}{|c|}{ Plasma } \\
\hline Total & 6.59 & 4.90 & $26-90$ & $(108)$ \\
\hline Testosterone & $4.91-5.59$ & 4.75 & $20-40,40-60$ and $60-80$ & $(109)$ \\
\hline$(\mathrm{ng} / \mathrm{mL})$ & 6.35 & 4.04 & $18-40$ and $70-85$ & (9) \\
\hline & 4.24 & 3.22 & $60-91$ & (63) \\
\hline & 4.8 & 4.6 and 4.9 & $30-40,41-50,51-60$ and $61-70$ & $(110)$ \\
\hline $\begin{array}{l}\text { Free Testosterone } \\
\text { (ng/dL) }\end{array}$ & 10.7 & 5.8 & $26-90$ & $(108)$ \\
\hline Estradiol $(\mathrm{pg} / \mathrm{mL})$ & 24.46 & 18.60 & $60-91$ & (63) \\
\hline $\begin{array}{l}\text { SHBG } \\
(\mathrm{nmol} / \mathrm{L}) \\
(\mathrm{ng} / \mathrm{mL})\end{array}$ & $\begin{array}{l}20.7 \\
2.76\end{array}$ & $\begin{array}{l}41.5 \\
7.66\end{array}$ & $\begin{array}{l}18-40 \text { and } 75-90 \\
60-91\end{array}$ & $\begin{array}{l}(9) \\
(63)\end{array}$ \\
\hline $\begin{array}{l}\text { FSH } \\
(\mathrm{mU} / \mathrm{L}) \\
(\mathrm{mIU} / \mathrm{mL})\end{array}$ & $\begin{array}{l}3.4 \\
8.71\end{array}$ & $\begin{array}{l}102 \\
10.27\end{array}$ & $\begin{array}{l}18-40 \text { and } 75-90 \\
60-91\end{array}$ & $\begin{array}{l}(9) \\
(63)\end{array}$ \\
\hline LH & & & & \\
\hline $\begin{array}{l}(\mathrm{ng} / \mathrm{mL}) \\
(\mathrm{U} / \mathrm{L})\end{array}$ & $\begin{array}{l}1.9 \\
4.2\end{array}$ & $\begin{array}{l}2.2 \\
6.3\end{array}$ & $\begin{array}{l}26-90 \\
18-40 \text { and } 75-90\end{array}$ & $\begin{array}{l}(108) \\
(9)\end{array}$ \\
\hline$(\mathrm{mIU} / \mathrm{mL})$ & 10.77 & 8.86 & $60-91$ & (63) \\
\hline \multicolumn{5}{|c|}{ Intra-testicular } \\
\hline $\begin{array}{l}\text { Testosterone } \\
(\mathrm{ng} / \mathrm{g})\end{array}$ & 408.50 & 461.77 & $60-91$ & $(63)$ \\
\hline$(\mathrm{nM})$ & 17.5 & 11.8 & $19-50$ and $70-90$ & $(111)$ \\
\hline Estradiol (ng/g) & 20.25 & 16.21 & $60-91$ & $(63)$ \\
\hline $\begin{array}{l}\text { Pregnenolone } \\
(\mathrm{ng} / \mathrm{g})\end{array}$ & 165.54 & 147.79 & $60-91$ & $(63)$ \\
\hline $\begin{array}{l}\text { Progesterone } \\
(\mathrm{ng} / \mathrm{g})\end{array}$ & 90.70 & 85.82 & $60-91$ & $(63)$ \\
\hline DHEA (ng/g) & 235.38 & 285.17 & $60-91$ & $(63)$ \\
\hline DHEAS (ng/g) & 254.90 & 239.89 & $60-91$ & $(63)$ \\
\hline INSL3 (ng/mL) & 1.8 & 1.0 & $19-50$ and $70-90$ & $(111)$ \\
\hline AMH (pM) & 44.9 & 27.4 & $19-50$ and $70-90$ & $(111)$ \\
\hline $\operatorname{InhB}(\mathrm{pg} / \mathrm{mL})$ & 175 & 103 & 19-50 and 70-90 & $(111)$ \\
\hline
\end{tabular}

Note: DHT, dihydrotestosterone; SHBG, sex hormone-binding globulin; DHES, dehydroepiandrosterone; DHEAS, dehydroepiandrosterone sulfate; $\mathrm{FSH}$, folliclestimulating hormone; $\mathrm{LH}$, luteinizing hormone; $\mathrm{AMH}$, anti-mullerian hormone; INSL3, insulin like peptide 3; InhB, inhibin B 
Table 3 - Major molecular alteration occurring in testes with age.

\begin{tabular}{|c|c|c|c|}
\hline Cell/structure & Specie & Alterations observed with aging & Ref. \\
\hline $\begin{array}{l}\text { Testicular } \\
\text { capsule }\end{array}$ & Rat & $\begin{array}{l}\text { Increased response to } \mathrm{NE} \text { and PGA2 and } \\
\text { unchanged response to } \mathrm{ACh}\end{array}$ & $(82)$ \\
\hline \multirow[t]{4}{*}{ Testes } & Mice & $\begin{array}{l}\text { Increased activity of gonadal GST in old } \\
\text { animals }\end{array}$ & $(75,112)$ \\
\hline & & $\begin{array}{l}\text { Reduced expression of CD68 and CD163, } \\
\text { macrophages markers }\end{array}$ & $(81)$ \\
\hline & Rat & $\begin{array}{l}\text { Decreased mitochondria function; } \\
\text { Increased proton leak, and expression and } \\
\text { activity of UCP2 }\end{array}$ & $(113)$ \\
\hline & Human & Increased levels of COX2 & $(79,80)$ \\
\hline \multirow[t]{4}{*}{ Leydig cells } & Rat & $\begin{array}{l}\text { Reduced concentration of LH receptors in } \\
\text { Leydig cells with age }\end{array}$ & $(72)$ \\
\hline & & $\begin{array}{l}\text { Decreased expression of } 11 \beta \text {-HDS type } 2 \\
\text { with age }\end{array}$ & $(88)$ \\
\hline & & $\begin{array}{l}\text { Reduced expression of RLF/INSL3 gene with } \\
\text { age }\end{array}$ & $(86)$ \\
\hline & & $\begin{array}{l}\text { Molecular changes in MAPK and cAMP } \\
\text { signaling related with Leydig cells } \\
\text { hypofunction in aging }\end{array}$ & $(114)$ \\
\hline \multirow[t]{4}{*}{ Sertoli cells } & Rat & $\begin{array}{llll}\text { Increased synthesis and } & \text { secretion of } \\
\text { transferrin and decreased } & \text { synthesis of } \\
\text { cathepsin L in old individuals } & & \\
\end{array}$ & $(37,42,90)$ \\
\hline & & $\begin{array}{l}\text { Loss of the expression of receptors for the } \\
\text { hormone serotonin in rats older than } 24 \\
\text { months of age }\end{array}$ & $(40)$ \\
\hline & Mice & $\begin{array}{l}\text { Alterations in cytoskeletal components (F- } \\
\text { actin, vimentin and cytokeratin) }\end{array}$ & (39) \\
\hline & Men & Accumulation of intracellular amyloid fibrils & $(95)$ \\
\hline \multirow[t]{3}{*}{ Germ cells } & Bovine & $\begin{array}{l}U C H L 1 \text { and SELP gene expression increases } \\
\text { with age and the number of UCHL1 positive } \\
\text { cells is higher }\end{array}$ & (99) \\
\hline & Mouse & $\begin{array}{l}\text { Genes down-regulated with age: Gpr107, } \\
\text { Tyrobp, Smad4, Ms4a7 and Mrc1 } \\
\text { Genes up-regulated with age: Gpr116, } \\
\text { Gpr146, Gpr56. Grb2, Icam1, Lims1, Lin52, } \\
\text { Selp and Trio }\end{array}$ & $(100)$ \\
\hline & & $\begin{array}{l}\text { Increased levels of mRNA for Cres gene and } \\
\text { protein levels with age }\end{array}$ & $(115)$ \\
\hline
\end{tabular}

Note: NE, norepinephrine; PGA2, prostaglandin A2; ACh, acetylcholine; GST, glutathion-S-transferase; UCP2, uncoupling protein 2; COX2, Cyclooxygenase $\square$ 2; LH, luteinizing hormone; $11 \beta$-HDS, 11 beta-hydroxysteroid dehydrogenase; RLF, relaxinlike factor; MAPK, Mitogen Activated Protein Kinase; cAMP, cyclic adenosine monophosphate; UCHL1, Ubiquitin carboxy-terminal hydrolase L. 
Testes. Cross-section showing the location of the seminiferous tubules, the vas deferens and the epididymis as well as the tunica albuginea. Schematic cross-section of a testicular tubules illustrating the germ cells at different stages of maturation within a somatic Sertoli cell. Leydig cells and vasculature are present in the interstitium. Major morphological, cellular and ultrastructural alterations associated with age in testis are indicated.

$254 \times 339 \mathrm{~mm}(300 \times 300$ DPI $)$ 